\title{
Realisasi Keputusan Pesamuhan Agung III MUDP Bali terhadap Pewarisan Anak Perempuan Bali Aga di Kabupaten Buleleng
}

\author{
I Komang Kawi Arta, Ketut Sudiatmaka, Ratna Artha Windari \\ Jurusan Ilmu Hukum \\ Universitas Pendidikan Ganesha \\ Singaraja, Indonesia
}

e-mail: \{kawi.arta, sudiatmaka, ratnawindari\}@undiksha.ac.id,

\begin{abstract}
Abstrak
Penelitian ini bertujuan untuk mengetahui (1) Penerimaan Bendesa Adat dan Masyarakat Desa Bali Aga Kabupaten Buleleng tentang isi Keputusan Pesamuhan Agung III/2010 MUDP Bali terkait Kedudukan Anak Perempuan Hindu dalam Pewarisan, (2) Realisasi isi Keputusan Pesamuhan Agung III/2010 MUDP Bali terkait Kedudukan Anak Perempuan Hindu Bali dalam Pewarisan di Desa Bali Aga Kabupaten Buleleng, (3) Implikasi dari realisasi Keputusan Pesamuhan Agung III/2010 MUDP Bali terhadap kaum Perempuan di Desa Bali Aga Kabupaten Buleleng. Jenis penelitian ini dengan metode pendekatan yuridis empiris. Data yang dikumpulkan dianalisis secara deskriptif kualitatif. Hasil penelitian menunjukkan, (1) Bendesa Adat dan masyarakat adat Desa Bali Aga Kabupaten Buleleng masih belum bisa menerima isi Keputusan Pesamuhan Agung III/2010 MUDP Bali, karena krama adat masih kuat mempertahankan dresta, awig-awig serta kebiasaan-kebiasaan yang mewaris hanya anak laki-laki di Desa Bali Aga Kabupaten Buleleng, (2) Belum terealisasi isi Keputusan Pesamuhan Agung III/2010 MUDP Bali. Hal ini dipengaruhi oleh budaya paternalistik yang sudah mengkristal sehingga Keputusan Pesamuhan Agung III/2010 MUDP Bali tersebut sulit untuk diterapkan sehingga timbul ucapan/gugon tuwon "anak mule keto dini" (memang seperti itu disini) pewarisan di Desa Bali Aga Kabupaten Buleleng, (3) Tidak ada suatu implikasi terhadap kaum perempuan di Desa Bali Aga Kabupaten Buleleng terkait realisasi isi Keputusan Pesamuhan Agung III/2010 MUDP Bali, karena tidak ada kaum perempuan yang berani menuntut untuk mendapatkan hak waris di masing-masing keluarganya.
\end{abstract}

Kata Kunci : Keputusan MUDP Bali, Kedudukan Perempuan, Pewarisan, Desa Bali Aga.

\footnotetext{
Abstract

The research was aimed at knowing (1) the acceptance of Bendesa Adat, the head of traditional village institution, and society of Bali Aga village, Buleleng regency about content of Pesamuhan Agung III/2010 MUDP Bali concerning position of Balinese Hindu Women in term of inheritance in Bali Aga village, Buleleng regency, (2) the realization of its content, and (3) the implication of its realization toward women in Bali Aga, Buleleng regency. This research was conducted by using a method of emperical juridical approach. In determining sample for this research, the researcher used purposive sampling technique. Then the collected data were analyzed in descriptive qualitative way. The result shows that, (1) Bendesa Adat and the society of Bali Aga village, Buleleng regency have not been able to accept the content of Pesamuhan Agung III/2010 MUDP Bali yet because they still strongly defend dresta, awig-awig (rules), as well as habits which only boys get the inheritance; (2) The content of Pesamuhan Agung III/2010 MUDP Bali decision has not realized yet. This is influenced by paternalistic culture which has been crystallized so that the decision is
} 
difficult to be applied so that it arises the saying or gugon tuwon "anak mule keto din" (indeed like it here) inheritance in Bali Aga Village Buleleng regency; (3) there is no implication toward the woman in Bali Aga about the realization of the result of Pesamuhan Agung III/2010 MUDP Bali since there are no women who dare to claim for inheritance rights in their respective families.

Keywords : Bali MUDP Decision, Woman Position, Inheritance, Bali Aga Village.

\section{PENDAHULUAN}

Masyarakat adat merupakan satu kesatuan dari Desa Pakraman atau Desa Adat, perihal mengenai Desa Pakraman atau Desa Adat ini diatur dalam Perda No 3 Tahun 2003 tentang Desa Pakraman dan lebih diakui pada aturan nasional pada Pasal 6 Ayat 1 UU No 6 Tahun 2014 tentang Desa yang menyebutkan Desa terdiri atas Desa dan Desa Adat. Ketentuan kedua aturan tersebut sudah sangat jelas Desa Pakraman atau Desa Adat itu diakui dan terdapat dasar hukum yang mengaturnya.

Hukum Adat bagi warga masyarakat adat mempunyai beberapa indikator penting dalam menunjukkan peranannya sebagai a tool of a social engineering (rekayasa sosial yang bertujuan untuk mengarahkan menuju keteraturan dan ketertiban yang orientasinya ingin menyasar pada aspek keadilan bagi masyarakat). Pertama, Hukum Adat yang realisasinya dapat berupa keputusan Adat dari hasil Pesamuhan Majelis Adat secara substantif memuat ketentuan yang mengatur tingkah laku manusia atau yang menjadi pedoman manusia untuk berperilaku guna menjaga keseimbangan kepentingan mereka dalam masyarakat. Kedua, memberikan peluang besar untuk perwujudan aspek keadilan bagi masyarakat dalam kerangka menerapkan prinsip persamaan dimuka hukum dan wajib menjunjung hukum dan pemerintahan tanpa terkecuali bagi masyarakat Indonesia secara keseluruhan (equality before the law), baik kaum laki- laki maupun perempuan. Ketiga, Hukum Adat dalam wujud Keputusan Majelis Utama Desa Pakraman dinilai memberikan kontribusi yang besar dalam penetapan kebijakan yang memenuhi unsur pelayanan publik bagi anggota masyarakat sampai ke tingkat lapisan paling bawah (Sudiatmaka, $2016: 772$ ).

Perihal Hukum Adat ini diatur dalam pasal 18 B Ayat 2 yang memuat; Negara mengakui dan menghormati kesatuan-kesatuan masyarakat hukum adat beserta hak-hak tradisionalnya sepanjang masih hidup dan sesuai dengan perkembangan masyarakat dan prinsip Negara Kesatuan Republik Indonesia, yang diatur dalam undang-undang. Hal ini tampak jelas bahwa keberadaan hukum adat tersebut legalitasnya diakui oleh negara dan ketentuan-ketentuan hukum adat itu mengikat masyarakat adat dan apabila dilanggar akan dikenakan sanksi adat. Namun dalam perkembangan hukum adat terkadang terjadinya tumpang tindih antara hukum adat dengan kebijakan yang mengatasnamakan adat.

Bahkan terkadang keputusankeputusan yang mengatasnamakan adat sering terjadinya pro-kontra dari kalangan masyarakat adat dan terkadang keputusankeputusan tersebut tidak sesuai dengan kondisi perkembangan prilaku masyarakat adat sehingga antara kebijakan yang ada dengan implementasi dilapangan terkadang jauh berbeda. Salah satu permasalahan yang muncul adalah pengaturan Anak Perempuan di Bali beragama Hindu yang berhak atas Warisan.

Hukum waris adat memuat peraturan-peraturan yang mengatur proses meneruskan serta mengoperkan barangbarang harta benda dari satu generasi ke generasi berikutnya. Proses tersebut seringkali dinamakan dengan "waris mewarisi". Di mana benda atau barang yang diwariskan itu bentuk dan jenisnya bermacam-macam dalam ketentuan hukum waris adat disebut "harta peninggalan" (Najih dan Soimin, 2014 : 306).

Hukum waris adat erat kaitannya dengan sifat-sifat kekerabatan atau struktur 
sosial yaitu masyarakat hukum adat sebagai subyek hukum adat serta pengaruhnya terhadap harta kekayaan atau harta perkawinan yang ditinggalkan yang berada dalam masyarakat itu. Selain itu, hukum waris adat juga dipengaruhi oleh perubahan-perubahan sosial budaya di mana hukum adat itu hidup seperti kuat lemahnya hubungan antara masyarakat hukum adat dengan keluarga dan individu (Rato, $2015:$ 113).

Pada umumnya perihal yang berhak mewaris di Bali itu adalah anak lakilaki, karena anak laki-laki ini merupakan penerus keturunan dari ayahnya dan pewarisan di Bali mengenal istilah lempeng ke purusa yang artinya pewarisan itu hanya di tujukan kepada laki-laki dan sistem pewarisannya bersifat patrilinial. Dalam pemberian warisan kepada anak laki-laki di Bali, selain warisan benda-benda materiil dan ada juga warisan berupa imateriil seperti halnya keanggotaan masyarakat hukum adat, keanggotaan sebagai krama subak, keanggotaan dan ayahan krama adat, banjar dan lain-lain. Hal tersebut sudah jelas ada dasarnya yang mengatur di awig-awig setiap Desa Pakraman yang ada di Bali dan prinsip-prinsip dalam kekeluargaan ke purusa sama dengan sistem kekeluargaan yang dianut dalam Kitab Manawa Dharmasastra, yang dikenal sebagai salah satu Kitab hukum Hindu. Hal ini tidak terlepas dari agama yang dianut mayoritas penduduk masyarakat Bali adalah agama Hindu (Dangin, 2015 : 6).

Pesamuhan Agung III yang di gelar pada tanggal 15 Oktober Tahun 2010, yang dituangkan dalam Keputusan Pesamuhan Agung MUDP Bali Nomor 01//KEP/PSM/3MDP Bali/X/2010, disebutkan bahwa hak ahli waris bagi kaum perempuan (Predana). Dalam Pesamuhan Agung Majelis Utama Desa Pakraman (MUDP) Bali tahun 2010 tersebut disebutkan ahli waris yang kawin keluar dan berstatus predana atau tidak berada di rumah dalam istilah Bali disebut ninggal kedaton terbatas, berhak atas setengah warisan guna kaya (hasil kerja/harta gono gini) orang tuanya, setelah dikurangi sepertiga untuk duwe tengah atau untuk perawatan orang tua. Dengan kata lain Perempuan berhak mendapat setengah dari harta warisan gunakaya yang diterima oleh saudara laki-lakinya yang berstatus purusa. Namun, ahli waris yang yang di kategorikan ninggal kedaton penuh atau pindah agama, tidak berhak atas sama sekali harta warisan, tetapi dapat diberikan bekal (jiwa dana) dari orang tuanya (http://www.balisaja.com/2015/12/perempu an-bali-kini-berhak-dapat.html).

Keputusan Majelis Utama Desa Pakraman (MUDP) Bali itu mengandung arti bahwa anak laki-laki berhak untuk mewaris dan anak perempuan juga berhak termasuk sebagai ahli waris. Namun Keputusan Majelis Utama Desa Pakraman (MUDP) Bali Tahun 2010 hingga saat ini belum terealisasi dengan baik, peneliti mengamati sebagian besar masyarakat Bali belum merealisasikan Keputusan Majelis Utama Desa Pakraman (MUDP) Bali Tahun 2010 tentang Perempuan berhak menerima warisan. Ini terlihat salah satu dalam penelitian yang dilakukan oleh Bapak Drs. Ketut Sudiatmaka, M.Si yang menghasilkan penelitian bahwa di Bali bagian Utara menerima dengan baik Keputusan Pesamuhan Agung III/2010 MUDP Bali terkait Anak Perempuan Hindu Bali berhak sebagai ahli waris di Bali dan pada Masyarakat Bali Selatan tidak menerima Keputusan Pesamuhan Agung III/2010 MUDP Bali terkait Anak Perempuan Hindu Bali berhak sebagai ahli waris.

Selain itu apalagi pada masyarakat khususnya pada masyarakat Adat Bali Aga yang masuk dalam lingkup Kabupaten Buleleng. Daerah Kabupaten Buleleng memiliki 7 (Tujuh) Desa yang termasuk dalam Desa Bali Aga yang diantaranya adalah Desa Adat Julah, Desa Adat Sembiran, Desa Adat Sidetapa, Desa Adat Cempaga, Desa Adat Tigawasa dan Desa Adat Pedawa Serta Desa Adat Banyuseri. Desa Bali Aga merupakan Desa adat yang tertua atau Bali mula yang penduduknya merupakan penduduk asli Bali. Masyarakat Bali Aga adalah kelompok masyarakat yang mendiami wilayah pegunungan. Masyarakat Bali Aga masih 
mengacu pada aturan tradisional adat Desa yang diwariskan nenek moyang mereka. Desa Bali Aga biasanya kental dengan adat istiadatnya, apapun perubahan pengaruh zaman sangat sulit untuk masuk didalam Desa Bali Aga. Ini terlihat bahwa Desa Bali Aga tersebut masih mempertahankan dengan kuat tradisinya yang terus dilakukan secara turun-temurun dan pola pikir masyarakat Bali Aga masih tradisional yang terus berusaha melestarikan nilai-nilai leluhur Bali yang telah diwariskan secara turun- temurun dari satu generasi ke generasi berikutnya. Pewarisan di Desa Bali Aga pada umumnya menggunakan sistem pewarisan patrilineal yaitu menarik garis keturunan laki-laki (Lempeng ke purusa). Selain itu juga dari pengamatan awal peneliti, bahwa di Desa Bali Aga masih belum merealisasikan isi Keputusan Pesamuhan Agung III MUDP (Majelis Utama Desa Pakraman) Bali Tahun 2010 terkait Perempuan Hindu Bali berhak menerima setengah dari hak waris purusa (laki-laki) setelah dipotong 1/3 untuk harta pusaka dan kepentingan pelestarian. Melihat dari proses timbulnya hukum adat itu pada umumnya muncul dari bawah sesuai dengan kebiasaan, norma dan sistem sosial serta terus berkembang hingga menjadi hukum adat. Namun dalam kenyataannya pada Keputusan MUDP Bali terkait anak perempuan hindu bali menerima setengah dari hak waris laki-laki setelah dipotong $1 / 3$ untuk harta pusaka dan biaya pelestarian tersebut munculnya aturan adat itu dari atas, oleh karena itu menyimpang dari suatu proses timbulnya hukum adat. Hal itulah yang sulit untuk diterima oleh masyarakat Bali Aga. Keputusan tersebut memberikan tujuan yang baik dan memberikan keharmonisan bagi kaum perempuan Hindu Bali tetapi kalau dilihat di Bali pada umumnya masih berpegang teguh dengan landasan ucapan "Anak dapet mula keto"(memang dapat seperti itu). Hal inilah yang mengindikasikan masyarakat Bali Aga sulit menerima perubahan. Dari hal tersebut peneliti tertarik untuk meneliti Keputusan Pesamuhan Agung III/2010 MUDP Bali terkait kedudukan anak perempuan Hindu dalam pewarisan dengan keberadaannya di Desa Bali Aga Kabupaten Buleleng karena hukum pewarisan adat Bali Aga pada umumnya memposisikan laki-laki yang berhak mewaris. Padahal Anak perempuan Hindu Bali itu mempunyai peran yang penting di dalam keluarga. Oleh karena itu dengan terealisasinya Keputusan tersebut akan memberikan dampak yang positif bagi kaum perempuan Hindu Bali pada umumnya dan kaum perempuan Bali Aga pada khususnya.

Penelitian bertujuan untuk mengetahui Penerimaan Bendesa Adat dan Masyarakat Desa Bali Aga Kabupaten Buleleng tentang isi Keputusan Pesamuhan Agung III/2010 MUDP Bali terkait Kedudukan Anak Perempuan Hindu dalam Pewarisan, Realisasi isi Keputusan Pesamuhan Agung III/2010 MUDP Bali terkait Kedudukan Anak Perempuan Hindu Bali dalam Pewarisan di Desa Bali Aga Kabupaten Buleleng, dan Implikasi dari realisasi Keputusan Pesamuhan Agung III/2010 MUDP Bali terhadap kaum Perempuan di Desa Bali Aga Kabupaten Buleleng.

Manfaat yang diperoleh dari penelitiani ini adalah : Bagi masyarakat Desa Bali Aga di Kabupaten Buleleng, di mana penelitian ini dapat dijadikan dasar sebagai pembentukan peraturan terutama dalam pembentukan awig-awig yang nantinya dapat melihat kebutuhan masyarakat dan kesejahteraan masyarakat khususnya bagi kaum Perempuan Hindu Bali; Bagi peneliti-peneliti lain yang sifatnya sejenis, hasil penelitian ini diharapkan dapat menambah referensi awal untuk melakukan kajian lebih dalam tentang fokus kajian Putusan Majelis Utama Desa Pakraman (MUDP) dan sebagai sumber informasi, khususnya mengenai realisasi isi Keputusan Majelis Utama Desa Pakraman (MUDP) bali terkait perempuan Hindu Bali dalam Pewarisan; Bagi Pemerintah khususnya Pemerintah Daerah Kabupaten Buleleng yang mempunyai hubungan dengan Majelis Madya Desa Pakraman (MMDP), hasil penelitian ini diharapkan dapat dijadikan pertimbangan dalam 
penerapan Keputusan Pesamuhan Agung III/MUDP Bali terkait kedudukan Anak perempuan Hindu Bali dalam Pewarisan.

\section{METODE PENELITIAN}

Berdasarkan fokus masalah penelitian yang di fokuskan di atas, maka penelitian ini secara metodologis menggunakan pendekatan yuridis empiris (Ali, 2016:30). Dengan rasionalitas untuk mengkaji kesenjangan dari Keputusan Pesamuhan Agung III/2010 Majelis Utama Desa Pakraman (MUDP) terkait Kedudukan Anak Perempuan dalam Pewarisan dengan realisasi di Desa Bali Aga Kabupaten Buleleng. Oleh karena itu penelitian ini akan dimulai dari obervasi awal untuk menentukan urgensi masalah, melakukan wawancara, studi dokumen, memfokuskan data dan mendeskripsikan data sesuai dengan alur penelitian kualitatif. Adapun alur pengolahan data kualitatif diawali dengan adanya pengumpulan data baik yang dilakukan dengan menggunakan teknik studi dokumen, teknik wawancara, teknik observasi. Setelah data terkumpul maka data akan direduksi, yaitu data yang telah dikumpul di rangkum dan yang diseleksi yang didasarkan pada fokus, kategori, maupun pokok permasalahan tertentu yang telah ditetapkan dan di rumuskan sebelumnya, dan pada akhir tahap ini semua data yang relevan diharapkan telah tersusun dan terorganisir sesuai dengan kebutuhan. Langkah selanjutnya adalah, setelah data terkumpul dan direduksi maka data akan disajikan , karena penyajian data merupakan tahap penampilan data dengan cara memasukkan data dalam sejumlah matriks yang diinginkan. Proses ini hanya bisa dilaksanakan setelah adanya proses reduksi data atas data yang direduksi dan disajikan tadi. Jadi berdasarkan hasil pemahaman dan pengertian, kemudian peneliti menarik kesimpulan sebagai jawaban atas permasalahan yang peneliti cantumkan (Wirantini, 2014 : 40)

\section{HASIL DAN PEMBAHASAN}

Desa Bali Aga merupakan Desa yang tertua di Bali. Pada umumnya masyarkat Bali Aga merupakan masyarakat yang sulit terkena pengaruh dan apalagi pengaruh tersebut hal-hal yang baru. Dalam perjalanan sejarah yang begitu panjang terutama setelah masuknya kekuasaan Majapahit di Bali yang membawa pengaruh baru bagi agama, budaya, dan lain-lain yang membuat masyarakat Bali Aga semakin sedikit bila dibandingkan dengan masyarakat Bali Majapahit , tetapi dalam kenyataannya hingga kini suku Bali Aga dan segala keunikannya masih melestarikan budaya leluhurnya. Sehingga masyarakat Bali Aga mempunyai keunikannya tersendiri. Yang termasuk Desa Bali Aga di Kabupaten Buleleng adalah Desa Pakraman Sidetapa, Desa Pakraman Cempaga, Desa Pakraman Tigawasa, Desa Pakraman Pedawa, Desa Pakraman Banyuseri dan Desa Pakraman Julah serta Desa Pakraman Sembiran. Dalam penelitian ini peneliti memfokuskan mengambil penelitian di 4 (empat) Desa Bali Aga Kabupaten Buleleng. Karena dari ke 4 (empat) Desa Bali Aga di Kabupaten Buleleng sudah mewakili dari 7 (Tujuh) Desa Bali Aga yang ada di Kabupaten Buleleng. Diantaranya, Desa Bali Aga Kabupaten Buleleng bagian Barat yaitu Desa Pakraman Cempaga dan Desa Pakraman Pedawa. Serta Desa Bali Aga Kabupaten Buleleng bagian Timur yaitu Desa Pakraman Julah dan Desa Pakraman Sembiran.

Pewarisan Adat di Bali sampai saat ini menganut Sistem Patrilinieal. Sistem Patrilineal, yaitu sistem keturunan/kekeluargaan yang menarik garis keturunan pihak nenek moyang laki- laki. Sistem ini, kedudukan dari pengaruh pihak laki-laki sangat menonjol (Suparman, 2014 : 41). Ketentuan hukum waris adat pada masyarakat patrilineal menentukan bahwa hanya keturunan laki-laki yang berhak untuk mewaris harta pusaka. Harta pusaka dapat dibedakan antara pusaka tinggi dan pusaka rendah. Harta Pusaka tinggi adalah harta peninggalan dari zaman leluhur, yang dikarenakan keadaanya, kedudukannya dan sifat yang tidak patut dan tidak pantas dibagi-bagi. Sedangkan 
harta pusaka rendah adalah harta yang ditinggalkan pada generasi diatas ayah, misalnya harta peninggalan kakek atau nenek yang keadaanya, kedudukannya dan sifatnya yang tidak mutlak untuk dibagi-bagi, baik penguasaan atau pemakaianya atau mungkin juga pemilikannya (Hadikusuma, $2015: 11$ ).

Dalam hal penerimaan Bendesa adat dan Prajuru/Pengurus adat maupun tokoh masyarakat di tempat penelitian masih ada menerima maupun yang masih belum bisa menerima Isi Keputusan Pesamuhan Agung III/2010 MUDP Bali tersebut. Tetapi yang menerima Keputusan tersebut hanya salah satu Bendesa Adat dengan alasan karena menurut pemikiran pribadinya dan Bendesa Adat tersebut merupakan kaum intelektual.

Keputusan No.01/Kep/PSM-3MDP

Bali/X/2010, 15 Oktober Tahun 2010 ini yang isinya "Wanita Bali menerima setengah dari hak waris purusa setelah dipotong 1/3 untuk harta pusaka dan kepentingan pelesatrian. Hanya jika kaum wanita Bali yang pindah ke agama lain, mereka tidak berhak atas hak waris. Jika orang tuanya ikhlas, tetap terbuka untuk memberikan jiwa dan atau bekal sukarela" (Setyawati, 2017 : 620). Keputusan ini memang memberikan suatu keadilan gender dan hak perempuan Bali tersebut diperhatikan. Tetapi masih ada Bendesa adat dan prajuru adat maupun tokoh masyarakat di Desa Bali Aga Kabupaten Buleleng yang masih belum bisa menerima Isi Keputusan Pesamuhan Agung III tersebut karena didasarkan atas suatu awigawig dan dresta yang masih diakui oleh krama adat. Awig-awig Desa Pakraman itulah yang kuat di pegang oleh masyarakat adat untuk dipertahankan bahwa anak lakilaki (Purusa) saja yang berhak mewaris. Selain itu juga jika diteliti sampai ke akar rumputnya masyarakat di Desa Bali Aga Kabupaten Buleleng masih banyak yang belum bisa menerima isi Keputusan Pesamuhan Agung III/2010 MUDP Bali terkait kedudukan anak perempuan Hindu Bali dalam pewarisan karena budaya paternalistik yang sudah mengkristal sehingga Keputusan
Pesamuhan Agung III/2010 MUDP Bali tersebut sulit untuk diterapkan sehingga ada ucapan "anak mule keto dini" (memang seperti itu disini).

Pandangan masyarakat Bali, pewaris adalah seorang ayah (laki-laki). Paham ini tampaknya dilandasi pemikiran bahwa dalam sistem kekerabatan kepurusa yang bersifat Patriarkhi, bahwa ayah adalah kepala keluarga, pencari nafkah dan pemilik harta keluarga yang diwarisi secara turuntemurun. Dalam logika ini, harta warisan di wariskan melalui garis atau pancer laki-laki, sehingga semua harta milik laki-laki, sedangkan perempuan bukan pemilik harta. Sebelum kawin, anak perempuan adalah milik dan tanggungjawab ayahnya, setelah kawin adalah milik suaminya. Pandangan ini di dasarkan atas ketentuan Pasal 3 Bab IX Kitab Manawa Dharmasastra yang berbunyi : Ayahnya yang melindungi selagi ia masih kecil dan setelah dewasa suaminyalah yang melindungi dan putra- putranya melindungi setelah ia tua, wanita tidak pernah layak bebas. Mencermati Pasal 3 tersebut wanita tidak layak sebagai pemilik harta karena selalu berada dalam tanggungjawab lakilaki (Sukerti, 2012 : 57).

Selain itu ditempat penelitian merupakan Desa Bali Aga. Desa Bali Aga (Bali Mula) ini merupakan Desa yang kuat memegang sistem serta adat-istiadatnya dan tidak atau sedikit kena pengaruh Majapahit, sehingga mempunyai perbedaan antara orang Hindu Majapahit dengan orang Hindu Bali Aga. Hal inilah yang menyebabkan suatu Keputusan Pesamuhan Agung III tersebut sulit untuk diterima oleh masyarakat Bali Aga Kabupaten Buleleng.

Selama ini pihak bendesa adat mengijinkan diadaknnya Sosialisasi terkait Isi Keputusan Pesamuhan Agung III/2010 MUDP Bali terkait Kedudukan Anak Perempuan Hindu Bali dalam Pewarisan, akan tetapi hingga saat ini belum pernah dilakukan sosialisasi baik oleh Majelis Utama Desa Pakraman (MUDP), Majelis Madya Desa Pakraman (MMDP) dan Majelis Alit Desa Pakraman, sehingga 
masyarakat belum mengetahui isi Keputusan tersebut.

Dalam mensosialisasikan isi Keputusan tersebut pasti akan muncul suatu perdebatan-perdebatan di kalangan masyarakat. Dengan munculnya perdebatan-perdebatan nantinya ada suatu titik temu di dalam masyarakat mengenai Isi Keputusan Pesamuhan Agung III/2010 MUDP Bali terkait Kedudukan Anak Perempuan Hindu Bali dalam Pewarisan. Sehingga masyarakat akan mengkaji dan memikirkan lebih dalam mengenai mana yang pantas diterapkan dalam pewarisan di keluarganya. Mengingat Majelis Utama Desa Pakraman (MUDP) memiliki tugas dan wewenang yang terdapat di dalam pasal 16 Perda Nomor 3 Tahun 2001 tentang Desa Pakraman adalah sebagai berikut :

a. Mengayomi adat-istiadat

b. Memberikan saran, usul dan memberikan pendapat kepada berbagai pihak perorangan, kelompok/lembaga, maupun pemerintah tentang masalahmasalah adat

c. Melaksanakan setiap keputusamkeputusan paruman dengan aturanaturan yang ditetapkan

d. Membantu menyurat awig-awig

e. Melaksankan penyuluhan adatistiadat secara menyeluruh

Sedangkan kewenangan Majelis Desa Pakraman (MDP) adalah sebagai berikut:

a. Memusyawaratkan berbagai hal yang menyangkut masalah-masalah adat dan agama untuk kepentingan Desa Pakraman

b. Sebagai penengah dalam kasuskasus adat yang tidak dapat diselesaikan pada tingkat Desa

c. Membantu menyelengarakan upacara keagamaan di Kecamatan, Kabupaten/Kota dan Provinsi.

Tugas dan kewenangan Majelis Desa Pakraman (MDP) tersebut diatas tentunya berdasarkan atas suatu aturan yang jelas, sehingga Majelis Desa Pakraman (MDP) mempunyai kewenangan yang jelas untuk mensosialisasikan Isi
Keputusan Pesamuhan Agung III tersebut. Pesamuhan Agung atau Paruman (setara dengan kongres) Majelis Desa Pakraman seluruh Bali. Paruman Agung inilah yang mengeluarkan keputusan-keputusan yang mengikat seluruh Desa Pakraman di Bali dan segenap Majelis Desa Pakraman (Budawati dkk, 2012 : 29).

Disamping disosialisasikan Keputusan tersebut, dalam menerapkannya juga perlu suatu dukungan dari Bendesa Adat dan Prajuru/Pengurus Adat, karena Bendesa Adat mempunyai tanggungjawab dalam seluruh kegiatan warga Desa yang melaksanakan tugastugasnya, dibantu oleh Prajuru/Pengurus Adat, sehingga Bendesa adat dan Prajuru/Pengurus Adat sebagai ujung tombak untuk menentukan keberhasilan dalam menerapkan suatu kebijakankebijakan adat dan dalam hal juga kaitannya dengan Keputusan Pesamuhan Agung III/2010 MUDP Bali terkait anak perempuan Hindu Bali dalam pewarisan.

Dalam Putusan Mahkamah Agung Republik Indonesia Nomor 4766/Pdt/1998, tertanggal 16 November 1999, mendalihkan bahwa :

"Anak perempuan di Bali berhak atas peninggalan dari Pewaris. Walapun sistem kewarisan di Bali sendiri menggunakan sistem kewarisan mayorat laki-laki, yang mengatur bahwa anak perempuan di Bali bukan merupakan ahli waris dari pewaris".

\section{Berdasarkan Surat Keputusan} Panitia Landreform Daerah Tingkat I Bali tertanggal 28 Mei 1962 No.2/Sk./XX/1962 dan hasil rapat Panitian Ad.Hoc Panitia Landreform Daerah tingkat I Bali tanggal 1 Oktober 1962 dirumuskan bahwa yang tergolong ahli waris adalah janda, anakanak baik laki-laki maupun anak perempuan atau anak laki-laki dan anak perempuan mempunyai hak yang sama (Sukerti, 2012 : 64). Dalam Kitab Manawa Dharmasastra di gambarkan kedudukan perempuan pada Bab III Sloka 58 dan 59 sebagai berikut :

a. Sloka 58 menyebutkan: 
"Bagi setiap warga yang tidak menghormati kaum perempuan, niscaya keluarga itu akan hancur lebur berantakan. Rumah dimana perempuannya tidak dihormati sewajarnya, mengungkapkan kutukan, keluarga itu akan hancur seluruhnya, seolah-olah dihancurkan oleh kekuatan gaib".

b. Sloka 59 menyebutkan :

"Oleh karena itu orang yang ingin sejahtera, harus selalu menghormati perempuan Kitab suci mewajibkan semua orang menghormati perempuan" (Pudja dan Sudharta. 1976/1977 : 150).

Pada Putusan Mahkamah Agung Republik Indonesia Nomor 4766/Pdt/1998 tertanggal 16 November 1999 dan Sloka 58, 59 serta Surat Keputusan dan hasil rapat Panitia Ad.Hoc panitia Landreform Daerah Tingkat I Bali tersebut diatas menggambarkan bahwa perlu diperhatikan suatu kesetaraan gender. Selain itu Putusan maupun Sloka tersebut menerangkan bahwa hak-hak anak perempuan sudah diperhatikan sejak lama. Hal tersebut harus menggugah masyarakat adat agar anak perempuan sudah waktunya untuk diperhatikan dan dihormati, sehingga tidak ada salahnya menghormati anak perempuan dengan cara memberikan suatu hak waris walapun tidak sama bagiannya dengan anak laki- laki.

Pewarisan di Desa Bali Aga Kabupaten Buleleng berdasarkan dresta, awig-awig dan kebiasaan-kebiasaan yang terus turun-temurun dilakukan sehingga belum merealisasikan Isi Pesamuhan Agung III/2010 MUDP Bali terkait kedudukan anak perempuan Hindu Bali dalam pewarisan. Namun di tempat penelitian secara tidak langsung anak perempuan itu diberikan suatu bekal sukarela atas kebijaksanaan dari orang tuanya dan ahli waris laki-laki (Purusa).

Pemberian kepada anak perempuan tergantung dari kesepakatan dan pertimbangan-pertimbangan keluarga serta istilahnya di tempat penelitian yaitu anak perempuan tidak diberikan tempatnya tetapi diberikan isinya yang artinya orang tua boleh memberikan harta gono-gini tetapi tidak waris secara turun-temurun. Secara tidak langsung sebenarnya masyarakat di Desa Bali Aga Kabupaten Buleleng sudah mempraktekkan isi Keputusan Pesamuhan Agung tersebut tetapi tidak sama persis dengan Isi Keputusan Pesamuhan Agung III/2010 MUDP Bali terkait kedudukan anak perempuan Hindu Bali dalam pewarisan. Terkadang saking sayangnya orang tua kepada anak perempuannya. Jika anak perempuan kawin diberikan bekal berupa benda bergerak seperti misalnya mobil maupun motor.

Pemberian secara tidak langsung kepada anak perempuan memang tidak sama dengan laki-laki tetapi kebijaksanaan orang tua yang memberikan bekal kepada anak perempuannya ternyata diterima oleh anak laki-laki. Jiwa dana merupakan harta bawaan yang dibawa masuk di dalam perkawinan sebagai bekal dan diharapkan dengan harta bawaan oleh anak perempuan yang kawin keluar mempunyai status dengan keluarga yang baru (keluarga suami). Pemberian Jiwa dana atau hibah kepada orang yang bukan ahli waris dapat diberikan sepanjang dalam batas-batas layak dan tidak merugikan ahli waris.

Hal demikian semacam legitieme portie dalam Kitab Undang-undang Hukum Perdata (KUHPerd). Ukuran layak menurut yurisprudensi adalah sebanyak-banyaknya sepertiga bagian dari seluruh harta kekayaan pewaris berdasarkan Keputusan Pengadilan Kertha Singaraja No.81/Sipil, tanggal 24 November 1939, harta warisan yang dapat diwarisi secara individual oleh para ahli waris (sistem kewarisan individual) adalah harta warisan yang bernilai nonmagis-religius (Sukerti, 2012 : 68). Berdasarkan Keputusan Mahkamah Agung tanggal 23 Agustus 1960, No. 225 K/Sip/1960, yaitu Hibah tidak memerlukan persetujuan ahli waris, Hibah tidak mengakibatkan ahli waris dari si pengibah tidak berhak lagi atas harta peninggalan dari sipengibah dan hibah wasiat tidak boleh merugikan ahli waris dari sipengibah 
(Hadikusuma, 2015 : 144). Artinya dalam Keputusan Pengadilan dan Keputusan Mahkamah Agung tersebut menunjukkan bahwa proses penghibahan dapat diberikan untuk anak perempuan dan Keputusan tersebut sudah terang memandang perempuan untuk mendapatkan suatu pemberian dari orang tuanya tanpa dihalangi oleh persetujuan dari pihak ahli waris (Purusa), serta hak- hak anak perempuan itu mulai untuk terus diperhatikan dengan memberikan suatu kebijaksanaan.

Jika kebijaksanaan itu terus bisa dilaksanakan dan diterapkan akan tercermin semangat kekeluargaan dan sifat hukum adat yang Dinamis, yang artinya hukum adat itu pada prinsipnya terus- menerus berubah dan perkembangan melalui keputusan-keputusan atau penyelesaianpenyelsaian yang dikeluarkan oleh masyarakat sebagai hasil temu pikir melalui permusyawaratan, sehingga memberikan kontribusi yang baik bagi proses perkembangan pewarisan anak perempuan di Desa Bali Aga Kabupaten Buleleng.

Memang dalam penerapannya untuk memberikan hak waris untuk anak perempuan tentu ada suatu kendalakendala didalamnya baik kendala akan ada suatu keributan maupun percekcokan di dalam keluarga, tetapi melihat dari hal tersebut perlunya suatu soasialisasi jelas mengenai Keputusan Pesamuhan Agung III/2010 MUDP Bali terkait kedudukan anak perempuan Hindu Bali dalam pewarisan, sehingga masyarakat Desa Bali Aga Kabupaten mengerti dan paham betul akan isi dari Keputusan tersebut baik warisan dalam bentuk apa saja yang boleh diberikan maupun yang tidak boleh diberikan untuk anak perempuan.

Selain itu Asas Keadilan yang didalamnya memuat keadilan berdasarkan status, kedudukan, dan jasa sehingga setiap keluarga pewaris mendapatkan harta warisan, baik bagian sebagai ahli waris maupun bagian bukan sebagai ahli waris, melainkan bagian jaminan harta sebagai anggota keluarga pewaris (Ali, 2008 : 9). Artinya jika asas keadilan ini bisa terlaksana dengan baik di setiap keluarga maka akan memberikan suatu dampak yang positif bagi kaum perempuan dalam hal pewarisan di Desa Bali Aga Kabupaten Buleleng.

Teori yang dikemukakan oleh Ter Haar (dalam Arka, 2016 : 61) memberikan ciri-ciri masyarakat-masyarakat hukum dikalangan rakyat sebagai berikut:

"Bilamana orang meneropong suku bangsa Indonesia manapun juga, maka tampaklah dimatanya di lapisan bagian bawah yang amat luasnya, suatu masyarakat yang terdiri dari gerombolan yang bertalian satu sama lain; terhadap alam yang tidak keliatan mata, terhadap dunia luar dan terhadap alam kebendaan, maka mereka bertingkah laku sedemikian rupa, sehingga untuk mendapatkan gambaran yang sejelas-jelasnya gerombolan tadi disebut masyarakat hukum (rechtsgemeenchappen)".

Dari ciri-ciri masyarakat hukum yang dikemukakan oleh Ter Haar, maka dalam masyarakat itu terdapat pergaulan hidup di dalam persekutuan-persekutuan itu untuk bertingkah laku sebagai satu kesatuan terhadap dunia luar, lahir dan

batin. Kesatuan masyarakat itu memiliki tata susunan yang tetap dan kekal. Kesatuan masyarakat itu memiliki pengurus sendiri, harta benda, dan hak milik keduiaan yang bersifat religius-magis.

Berdasarkan teori diatas, Hukum adat mempunyai keberagaman yang luas dan kesatuan masyarakat adat yang mempunyai tata susunan yang tetap dan kekal di setiap daerah. Bahkan khususnya hukum adat di setiap Desa Pakraman di Bali mempunyai keberagaman maupun tradisi yang berbeda-beda di setiap Desa Pakraman, sehingga apapun kebijakankebijakan yang mengatasnamakan adat harus sesuai dengan Desa Kala patra.

Realisasi Keputusan Pesamuhan Agung III/2010 MUDP Bali terkait kedudukan anak perempuan Hindu Bali dalam pewarisan tidak memberikan suatu implikasi terhadap kaum perempuan di Desa Bali Aga Kabupaten Buleleng. Hal ini dibuktikan dengan tidak adanya kaum 
perempuan yang berani menuntut untuk mendapatkan hak waris di masing masing keluarganya.

Memang isi awig-awig sesuai dengan dresta atau Desa Kala Patra, tetapi Keputusan Pesamuhan Agung III/2010 MUDP Bali terkait anak perempuan Hindu Bali dalam pewarisan bersifat yuridis formal dan keberadaan Majelis Desa Pakraman (MDP) tersebut di atur di dalam Perda Nomor 3 Tahun 2001 tentang Desa Pakraman, sehingga Majelis Desa Pakrman (MDP) sah keberadaanya di mata hukum dan selain itu juga Keputusan- keputusan Majelis Desa Pakraman (MDP) itu bersifat mengikat bagi Desa Pakraman yang ada di Bali. Namun hal yang dimaksud harus terakomodir terlebih dahulu di dalam awigawig Desa Pakraman sehingga bisa menjadi pedoman maupun menjadi kebiasan-kebiasaan yang bersifat mengikat bagi masyarakat adat.

Jika dilihat dari implikasi positif maupun negatif dari realisasi Keputusan Pesamuhan Agung III/2010 MUDP Bali terhadap kaum perempuan di Desa Bali Aga Kabupaten Buleleng memang akan memberikan dampak yang positif bagi anak perempuan di Desa Bali Aga Kabupaten Buleleng, tetapi akan berpengaruh negatif pada anak laki-laki. Anak laki-laki yang memikul suatu kewajiban yang tinggi dalam keluarga bisa sangat menuntut kaum perempuan yang mendapatkan warisan. Kalau berbicara implikasi tentunya ada yang di rugikan dan ada yang di untungkan, jadi perlunya suatu sikap kesadaran diri akan yang mana patut diperhatikan.

Dalam Era Globalisasi dan emansipasi wanita secara tidak langsung anak perempuan di Desa Bali Aga Kabupaten Buleleng dilihat dari segi kesetaraan dalam hal pendidikan sudah diberikan oleh orang tuanya tetapi dalam bentuk warisan belum bisa diberikan. Jika dilihat dalam Sloka 96 IX Manawa Darmasastra menyebutkan : "Untuk menjadi lbu perempuan itu diciptakan, dan untuk menjadi ayah laki-laki diciptakan, karena itu upacara keagamaan ditetapkan dalam Weda untuk dilaksanakan suami dan istrinya“. Dalam Sloka 96 ini mengandung arti bahwa tidak ada perbedaan laki-laki dengan perempuan yang diangkat statusnya, baik yang berhubungan dengan masalah duniawi ataupun masalah kewajiban suci. Karena bagi ayah dan ibu mereka keduanya lahir dari badan yang sama "Manu Smerti mengumpamakan perempuan seperti bumi/pertiwi/tanah dan laki-laki adalah benih atau bibit, antara bumi dan bibit mempunyai kedudukan dan peran yang sama dalam menciptakan kehidupan. Semangat moral ini menandakan prinsipnya menempatkan laki-laki maupun perempuan dalam mitra yang sejajar (Utari, 2012 : 3).

Jadi perlunya masyarakat adat memahami akan suatu prinsip moral yang terkandung di dalam Sloka 96 tersebut sehingga bisa menempatkan antara anak laki-laki dan perempuan mempunyai posisi yang sejajar. Sehingga dalam Hukum Adat Bali dalam kaitannya dengan Tri Hita Karana pada hubungan manusia dengan manusia bisa terwujud dengan baik dan juga bisa menimbulkan suatu keharmonisan, apabila Sloka tersebut diperhatikan maupun dilaksanakan dengan baik.

\section{SIMPULAN DAN SARAN}

Dalam hal Penerimaan Bendesa adat dan Prajuru/Pengurus adat maupun tokoh masyarakat Desa Bali Aga Kabupaten Buleleng masih belum bisa menerima Isi Keputusan Pesamuhan Agung III/2010 MUDP Bali terkait kedudukan anak perempuan Hindu Bali dalam pewarisan, karena budaya paternalistik yang sudah mengkristal sehingga Keputusan Pesamuhan Agung III/2010 MUDP Bali tersebut sulit untuk diterapkan sehingga ada ucapan "anak mule keto dini" (memang seperti itu disini). Hal inilah yang menyebabkan suatu Keputusan MUDP tersebut sulit untuk diterima sampai ke akar rumputnya di Desa Bali Aga Kabupaten Buleleng.

Pewarisan di Desa Bali Aga Kabupaten Buleleng berdasarkan dresta,awig-awig dan kebiasaan-kebiasaan 
yang terus turun-temurun sehingga belum merealisasikan Isi Keputusan Pesamuhan Agung III/2010 MUDP Bali terkait kedudukan anak perempuan Hindu Bali dalam Pewarisan. Namun terkadang anak perempuan di Desa Bali Aga Kabupaten Buleleng secara tidak langsung diberikan suatu bekal sukarela atas kebijaksanaan dari orang tuanya dan ahli waris laki-laki (Purusa).

Keputusan tersebut tidak memberikan suatu implikasi terhadap kaum perempuan di Desa Bali Aga Kabupeten Buleleng. Hal ini dibuktikan dengan tidak ada kaum perempuan yang berani menuntut untuk mendapatakan hak waris di masingmasing keluarga dan Keputusan MUDP tersebut bersifat yuridis formal dan keberadaan Majelis Desa Pakraman (MDP) tersebut diatur di dalam Perda Nomor 3 Tahun 2001 tentang Desa Pakraman, sehingga Majelis Desa Pakraman (MDP) sah keberadaanya di mata hukum dan selain itu juga Keputusan-Keputusan Majelis Desa Pakraman (MDP) itu bersifat mengikat bagi Desa Pakraman yang ada di Bali.

Bagi Bendesa Adat dan Prajuru/Pengurus Adat Desa Bali Aga Kabupaten Buleleng, disarankan agar mensosialisasikan Isi Pesamuhan Agung III/2010 MUDP Bali terkait kedudukan anak perempuan Hindu Bali dalam Pewarisan, sehingga krama adat mengetahui jelas tentang isi Keputusan tersebut. Bagi masyarakat adat Desa Bali Aga Kabupaten Buleleng disarankan agar mulai mempertimbangkan anak perempuan dengan cara memberikan suatu kebjiaksaan-kebijakaan berupa bekal sukarela pada saat ia kawin dan biarpun tidak berupa waris tetapi itu akan sangat menghormati dan menghargai anak perempuan di Desa Bali Aga Kabupaten Buleleng, sehingga keadilan gender bisa terwujud dengan baik. Bagi Majelis Utama Desa Pakraman (MUDP) diharapkan agar mensosialisasikan Isi Keputusan Pesamuhan Agung III/2010 MUDP Bali terkait kedudukan anak perempuan Hindu Bali dalam Pewarisan di Desa Bali Aga Kabupaten Buleleng, agar masyarakat Bali
Aga Kabupaten Buleleng memahami lebih spesifik tentang Isi Keputusan Pesamuahan Agung III terkait anak perempuan berhak mewaris. Selain itu dalam Keputusan Pesamuhan Agung III tersebut memang memberikan suatu hak waris kepada anak perempuan. Namun perlu juga dicantumkan dengan jelas kewajiban-kewajiban yang harus dilaksanakan, sehingga dengan memberikan hak tentu harus diimbangi dengan kewajiban yang jelas kepada anak perempuan Hindu di Bali pada umumnya maupun di Desa Bali Aga Kabupaten Buleleng pada khususnya dan Bagi peneliti yang sejenis lainnya, karena keterbatasan waktu peneliti dalam penelitian ini, maka di sarankan bagi peneliti yang selanjutnya agar meneliti masalah-masalah lainnya yang mempunyai hubungan dalam penelitian ini.

\section{DAFTAR PUSTAKA}

Ali, Zainuddin. 2008. Pelaksanaan Hukum Waris di Indonesia. Jakarta: Sinar Grafika

Ali, Zainuddin. 2016. Metode Penelitian Hukum. Jakarta: Sinar Grafika

Arka, I Wayan. 2016. Desa adat sebagai subyek hukum perjanjian. DenpasarBali:Universitas Dwijendra dan bekerjasama dengan Udayana University Press

Budawati, Ni Nengah dkk. 2012. Payung Hukum Adat Untuk keluarga Bali, Denpasar: Komunitas untuk Indonesia yang adil \& setara (KIAS)

Dangin, Ni Luh Gede Isa Praresti dkk. 2015. "Kedudukan Hak Mewaris Wanita Hindu dalam Sistem

Hukum Adat Bali". Tersedia pada http://download.portalgaruda.org/ article.php?article (diakses tanggal 23 September 2017)

Hadikusuma, H. Hilman. 2015. Hukum Waris Adat. Bandung: PT Citra Aditya Bakti

http://www.balisaja.com/2015/12/pere mpuan-bali-kini-berhak-dapat.html (diakses senin, 11 September 2017) 
Keputusan Majelis Utama Desa Pakraman. 2010. Hasil-hasil Pasamuhan Agung III MDP Bali, No. 01/KEP/PSM3/MDP Bali/X/2010.

Najih, Mokmhammad dan Soimin. 2014. Pengantar hukum Indonesia. Malang: SetaraPress.

Pudja dan Rai Sudharta. 1976/1977. Kitab Manawadharma Sastra. C.V. JUNASCO.

Rato,Dominikus. $2015 . \quad$ Hukum Perkawinan dan Waris Adat di Indonesia. Yogyakarta: LaksBang PRESSindo.

Peraturan Daerah Propinsi Bali Nomor 3

Tahun 2001 tentang Desa

Pakraman. Lembaran

Daerah Provinsi Bali Tahun 2003 No.29 Seri D No 29

Undang-undang No. 6 Tahun 2014 tentang Desa.Lembaran

Negara Republik Indonesia Tahun 2014 No. 7, Tamabahan Lembaran Negara Republik I ndonesia No 5495

Sudiatmaka, Ketut. 2016."Realisasi Isi Keputusan Pesamuan Agung III MUDP Bali No.01/KEP/PSM3MDP BALI/X/2010 Terkait dengan Anak Perempuan termasuk sebagai berhak mewaris: Studi kasus di Kabupaten Buleleng. Vol. 5, No. 1, April 2016

Sukerti, Ni Nyoman. 2012. Hak Mewaris Perempuan Dalam Hukum Adat Bali Sebuah Studi Kritis. Denpasar- Bali: Udayana University Press.

Suparman, H. Eman. 2014. Hukum Waris Indonesia dalam Perspektif Islam, Adat, dan BW. Bandung: PT Refika Aditama

Setyawati, Ni Kadek. 2017. Kedudukan Perempuan Hindu Menurut Hukum Waris Adat Bali dalam Perspektif Kesetaraan Gender. Tersedia pada

http://ejournal.ihdn.ac.id/index.ph $\mathrm{p} / \mathrm{JPAH} /$ article/ (diakses tanggal 3 Januari 2018)

Undang-Undang Dasar Negara Republik Indonesia Tahun 1945, No.6

Utari, Ni Ketut Sri. 2012. Mengikis Ketidakadilan Gender Dalam Adat Bali: Jurnal Studi Gender SRIKANDI. Tersedia pada https://ojs.unud.ac.id/index.ph p/sri kandi/article/ (diakses tanggal 1 November 2017)

Wirantini, Luh. 2014. Sengketa Tanah setra karang rupit di Desa Pakraman Temukus, Kecamatan Banjar, Kabupaten Buleleng. Singaraja : Universitas Pendidikan Ganesha 